\title{
Convergence and Divergence Dynamics in British and French Business Schools: How Will the Pressure for Accreditation Influence these Dynamics?
}

\author{
Lisa Thomas, Jon Billsberry, ${ }^{1}$ Véronique Ambrosini ${ }^{2}$ and Harry Barton ${ }^{3}$ \\ IESEG School of Management LEM-CNRS, Socle de la Grande-Arche, 1 parvis de la Defense, 92044 \\ Paris-La Defense cedex, France, ${ }^{1}$ Deakin University, Department of Management, Burwood, Victoria 3125, \\ Australia, ${ }^{2}$ Monash University, Department of Management, 900 Dandenong Road, Caulfield East, Victoria \\ 3145, Australia, and ${ }^{3}$ Nottingham Trent University, Burton Street, Nottingham NG1 4BU, UK \\ Corresponding author email: v.ambrosini@monash.edu
}

\begin{abstract}
This paper focuses on convergence and divergence dynamics among leading British and French business schools and explores how the pressure for accreditation influences these dynamics. We illustrate that despite historical differences in approaches to management education in Britain and France, these approaches have converged partly based on the influence of the American model of management education but more recently through the pursuit of accreditation, in particular from the Association to Advance Collegiate Schools of Business and the European Quality Improvement Standard. We explore these dynamics through the application of the resource-based view of the firm and institutional theory and suggest that, whilst achieving accreditation is a necessary precursor for international competition, it is no longer a form of competitive advantage. The pursuit of accreditation has fostered a form of competitive mimicry reducing national distinctiveness. The resource-based view of the firm suggests that the top schools need a more heterogeneous approach that is not easily replicable if they are to outperform the competitors. Consequently, the convergence of management education in Britain and France will become a new impetus for divergence. We assert that future growth and competitive advantage might be better achieved through the reassertion of national, regional and local cultural characteristics.
\end{abstract}

\section{Introduction}

Business schools constitute a business sector in their own right (Starkey and Tiratsoo, 2007); they profit from, and add to, the world economy (Durand and Dameron, 2011). This sector is internationalizing and is increasingly competitive (Dameron and Durand, 2009). Schools have

We would like to thank Professor Yochanan Altman and three anonymous reviewers for their insightful comments, which have helped us develop a clearer and more elaborated argument. responded to competitive pressures by pursuing accreditation, 'a quality assurance scheme that certifies that accredited schools have the structures and processes in place necessary to meet their stated objectives and continually improve performance' (Zammuto, 2008, p. 260), and by trying to climb the global rankings, both of which they believe will bring competitive differentiation (McKee, Mills and Weatherbee, 2005). This is important because students make international study decisions primarily on their perceptions of the overall quality of the country's education institutions, influenced by the highly visible role 
of data in benchmarking rankings (Lambert, 2008; McKee, Mills and Weatherbee, 2005; Noorda, 2011). Within the European Union, cross-border higher education initiatives have aided the competitive stance of European higher education institutions with the European Commission for Education and Training committing to the standardization of national systems and the European Commission's support for the Bologna Process (Ahola, 2005). Such policies, along with the increased popularity of European business schools (B-schools), mean that regional and international competition is intensifying (Chisholm, 2011; Tullis and Camey, 2007).

To explore the impact of these accreditation forces on European B-schools, we have chosen to examine those in Britain and France. These are some of the longest established B-schools in Europe and are interesting to compare and contrast because their roots are quite different offering contrasting trajectories. Whilst British B-schools developed within colleges and universities and therefore began life with an academic focus (Üsdiken, 2004), the roots of French B-schools lie in the 'Grande Ecoles' and the Chambers of Commerce leading to an emphasis on professional and technical training and finding solutions to real-world problems (Gröschl and Barrows, 2003; Ramirez, 2004). The nature of management education (ME) in the B-schools in these two countries continues to be influenced by these differing histories, but nevertheless both groups of B-schools are similarly consumed by the drive for accreditation and the benefits they hope it will bring.

For B-schools in both these countries, issues such as the influence of globalization and innovation, the value impact of research and the importance of clear perspectives about corporate social responsibility and leadership are fundamental to competitive success (Thomas and Cornuel, 2011). For British B-schools in particular, the impetus to compete internationally is a result of the change in government policy concerning the status of foreign students, an emphasis on conducting collaborative research, the introduction of the European Commission's Erasmus mobility programme, the search for additional funding as a consequence of reduced funding from central government, and the pursuit of excellence (Ayoubi and Al-Habaibeh, 2006). Similar competitive pressures apply to French B-schools (Grande
Ecoles de Commerce; GECs) where the ability to publish in high quality international journals has become a competitive necessity to attract faculty and students and to promote their international credibility (Thietart, 2009). In addition, the Government has granted universities more autonomy, which presents further competitive challenges to the GECs (Kumar and Usunier, 2001).

Current and future competitive strategies within the B-school sector are likely to result in the increased use of global benchmarks to assess the performance of institutions. The European Foundation for Management Development's (EFMD's) European Quality Improvement Standard (EQUIS) and the Association to Advance Collegiate Schools of Business (AACSB) have become the foremost bodies in this respect and accreditation with them is already a key driver for B-schools in mapping their strategic positions within the competitive environment (Thietart, 2009; Tullis and Camey, 2007). Accreditation has provided the mechanism to differentiate one B-school from another at national and international level giving accredited schools a competitive advantage based on quality improvement within programmes, curriculum content and strategic planning. Simultaneously, however, homogenization is occurring, as progressively more and more schools seek to gain accreditation such that accreditation no longer gives an individual institution any distinctive identity. Consequently, convergence amongst B-schools is happening whereby national and regional heterogeneity has given way to a superior universal form, and this form is being diffused and absorbed across the sector (Jamali and Neville, 2011). EQUIS and AACSB accredited B-schools are all able to claim excellence and argue that they are 'world class'.

To explore how accreditation influences convergence and divergence dynamics, we focus on the practices of British and French B-schools. Adopting a resource-based view (RBV) of the firm and institutional theory arguments, we suggest that whilst, at first, accreditation was a means of gaining competitive advantage, this is no longer the case as more and more schools are becoming accredited. Instead, we argue that accreditation has become a necessary prerequisite condition for world class B-schools. It helps establish an externally visible reputation for high quality. We also argue that homogenization 
resulting from accreditation will in itself create the impetus for divergence as B-schools will begin to adopt differentiation strategies to achieve competitive advantage. However, we contend that, when doing this, they will still adhere to the structures of the accreditation bodies, as losing accreditation would be too risky. To contextualize our study, we present an overview of these dynamics within the ME sector in Britain and France by tracing the comparative history and current issues facing B-schools in these countries. We then present our theoretical argument which we validate with interview data and conclude with our implications for future strategies of British and French B-schools. In doing so we contribute to the ongoing debate in the British Journal of Management (and others) about the future of B-schools (e.g. Durand and Dameron, 2011; Starkey and Tiratsoo, 2007; Thomas and Wilson, 2011).

\section{Convergence and divergence dynamics}

As we shall explain below, whilst British and French B-schools have evolved over 50 years from inherently different cultures, economies, educational models and ways that managers practise their profession, B-schools from both countries find themselves competing at national and international levels, adopting increasingly similar business models. Cultural values and differentiation advantages that had led to international difference are now being eroded. Accreditation bodies have become powerful influences on institutions' strategic positioning; they transcend national boundaries and have become a major factor homogenizing ME around the globe. Employing institutional theory in analysing forces of convergence and divergence, we suggest that B-schools are supported and constrained by dominant accreditation mechanisms. Institutional theory is relevant to our study since it asks important questions about how organizational choices are shaped, mediated and channelled by the institutional environment (Jamali and Neville, 2011). Whilst leading B-schools may be differentiated with reference to current common benchmarks and ranking systems at national and international level (Table 1), we focus throughout our arguments on those British and French schools that are both EQUIS and AACSB accredited. As such, our organizational field comprises those institutions operating in the same domain as indicated by the similarity of services offered, operating with similar structures and activities, and which face similar competitive pressures (McKee, Mills and Weatherbee, 2005).

Both Dameron and Durand (2009) and Tiratsoo (2004) argue that the prime cause of institutional isomorphism in the higher education sector has been the American model of ME whereby accredited schools and those in pursuit of accreditation are playing a game of catching-up with American schools. This has led to discussions among European B-schools about the need for alternative scenarios based on a combination of imitation and differentiation (Nioche, 2007). Incorporating these arguments and employing the RBV, we shall argue that, influenced by accreditation mechanisms, the convergence of $\mathrm{ME}$ between Britain and France will become a new impetus for divergence that involves novel adaptation rather than mere accommodation of a dominant model. Thus, divergence will be based on local contexts of operation, local resources and constraints, and local choices (Cret, 2007). Because of their specific and markedly different heritage, briefly described below, British and French schools provide an interesting focus for studying convergence and divergence dynamics in B-schools, and it provides ground for a theoretical discussion into accreditation processes. Our aim here is not to critique the accreditation mechanisms, but rather to explore the role of these accreditation mechanisms in the convergence and divergence dynamics and the implications for future strategies of British and French B-schools.

\section{Comparative history of management education in Britain and France}

\section{Evolution in France}

Although managerial training in France has roots going back to the late 18th century (Ramirez, 2004), it developed rapidly after the Second World War. This training matched the hierarchical and formal organization of French firms, which is closely linked to tiers of cadres (Granink, 1972; Ramirez, 2004). The Grande Ecoles, which include schools of engineering and administration (e.g. Ecole des Mines established in 1783, Ecole Polytechnique, established in 1784, and l'Ecole 


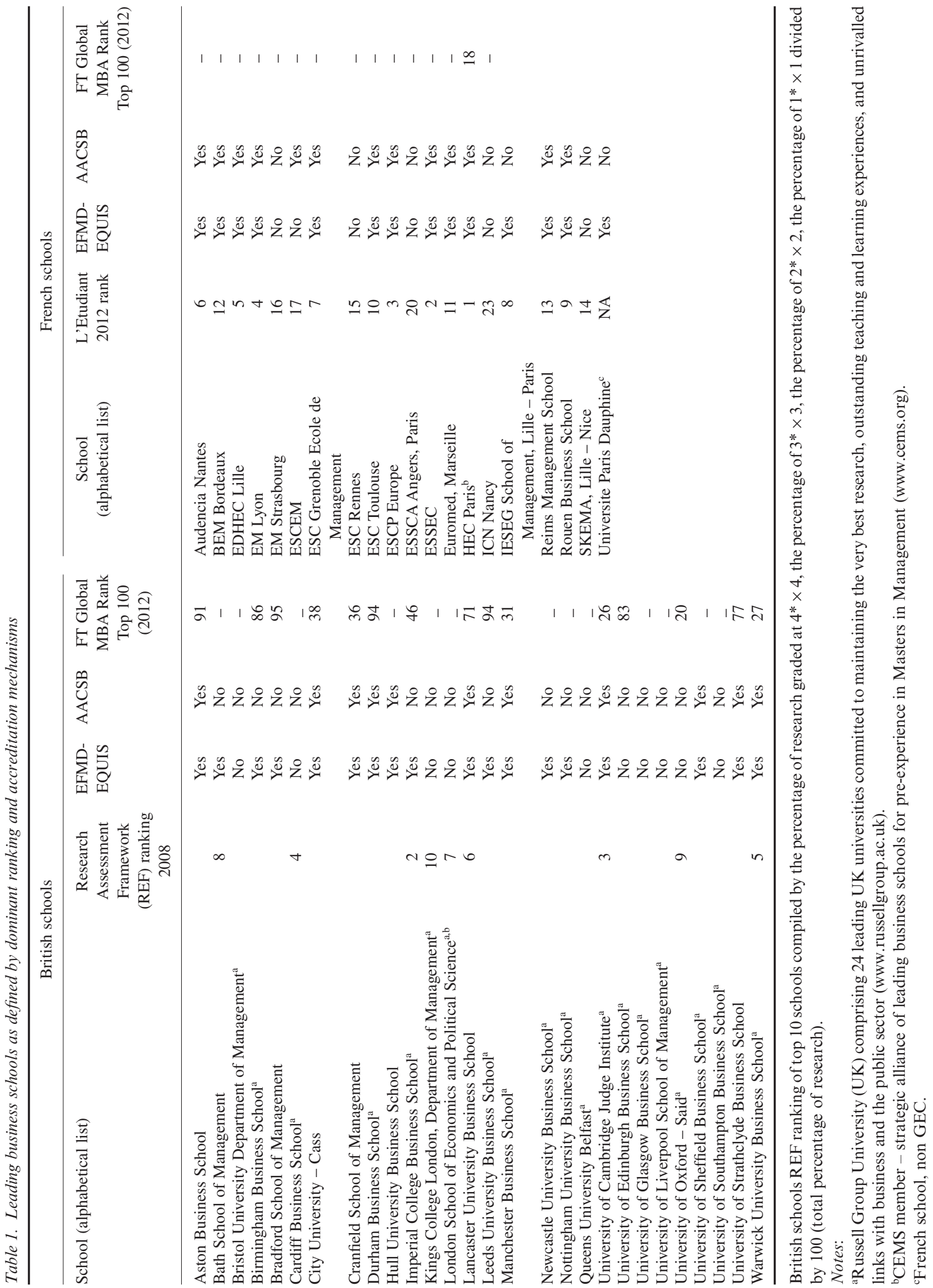


Nationale d'Administration, established in 1945), defined the skills of a top cadre of executive managers with emphasis placed on a logical and intellectual approach to problem-solving rather than a practical approach (Ramirez, 2004). The first GEC was founded in Paris in 1819 (later taken over by the Paris Chamber of Commerce in 1869 and now ESCP Europe) and it was modelled on the engineering schools (Kumar and Usunier, 2001). Until the early 1970s, the GECs were typically considered 'trade schools' because of their emphasis on professional and technical training rather than academic institutions (Gröschl and Barrows, 2003). GECs were established outside the public university system and instead they were embedded in the vocational chambers of commerce (Durand and Dameron, 2008; Ramirez, 2004).

The National Foundation for Management Development (Fondation Nationale pour l'Enseignement de la Gestion des Entreprises) was created in the late 1960s to close the gap between what was perceived as the GECs' outdated training of the future management elite of French companies, which did not seem to be adequate to face the economic challenge of American multinationals in Europe (Thietart, 2009). Schools began to introduce case method and new content including marketing, finance, strategy and human resource management into their curricula (Kumar and Usunier, 2001). These curricula resembled the American MBA with close links to the business world and emphasis on praxis rather than academic theory (Ramirez, 2004). The clearest manifestation of the American model within France was the establishment of the Institut Européen d'Administration des Affaires (INSEAD) in 1958 sponsored by the Paris Chamber of Commerce, the Ford Foundation and several French and American corporations (Kipping, Üsdiken and Puig, 2004). Even though elsewhere in French education the American influence remained limited, this signified an important change within B-schools; increasingly there was a recognition that ME should be taught by full-time professional academics and less by part-time business executives. In France, ME has always been located in the higher education system, which retains its highly elitist and status-driven nature (Kumar and Usunier, 2001; Ramirez, 2004). This elite identity of ME has been fostered by limiting entrance to B-schools through strict selection.
The high visibility of the careers of successful graduates has further reinforced the prestige of the institutions (Durand and Dameron, 2008; Vandenabeele and Van de Walle, 2008).

Over the last three decades French B-schools have witnessed increased internal competition resulting from the increased autonomy granted to universities. Initially this competition arose from the creation in the mid-1950s of a one-year type MBA programme within the university sector by the Institut d'Administration des Entreprises. Since then, competition has increased with more universities getting involved, e.g. in 1968 the Université Paris-Dauphine was established focusing solely on management and economics. Since the 1990s, increasing state involvement in improving faculty, compensation and infrastructure has improved the French university system (Kumar and Usunier, 2001). Nevertheless, thanks to the reputation they developed over time, the GECs have managed to maintain their prestige.

\section{Evolution in Britain}

The development of ME in Britain has been different from that in France as early business education took place in universities and colleges (Üsdiken, 2004). Subjects such as accounting and economics had been taught in British universities for over a century (Engwall and Danell, 2011; Watson, 2006). However, British universities showed some resistance towards vocational training and growth of ME was initially hesitant (Wilson, 1996). Management studies were felt to be unsuitable for university study with organizations left to train their employees. This is illustrated by recruitment practices for upper and middle managers. In Britain, such people were hired from within business rather than from social and educational elites, as was the case in France (Granink, 1972). As a result, Britain has been a latecomer to ME compared with France and a rather reluctant one (Gröschl and Barrows, 2003; Thomas, 2008; Thomas and Wilson, 2011). Before 1945 , ME was offered by just a handful of universities and colleges as part of Bachelor in Commerce degrees with some professional societies running their own courses in management (Tiratsoo, 2004).

In the 1960s, academics and industrialists decided that something should be done to improve Britain's competitive position and pro- 
posed the establishment of a number of B-schools with the remit of improving management quality (Tiratsoo, 2004). For this, Britain looked to America for a system of producing properly qualified managers. Much support was provided by UK and American agencies such as the AngloAmerican Council on Productivity. Technical assistance money helped launch management studies at Loughborough College (now Loughborough University) and Ford Foundation grants helped establish London Business School in 1965 and Warwick Business School several years later. Institutions such as Henley (1945) and Ashridge (1957) had already been established as independent executive education institutions. At undergraduate level, business education developed within the polytechnics and the new universities established by government initiative in the 1960s. Also at this time, MBA degrees following the American model were offered at London and Manchester Business Schools (Thomas and Wilson, 2011). The adoption of the American model has caused tension between industry, the government and academics since its emergence in the 1960s. Universities have traditionally been very cautious about introducing new syllabi and the introduction of a new discipline, and an American one at that, met with some resistance (Tiratsoo, 2004).

At first, schools were set up as autonomous institutions within existing university structures. Staff members in long-established subject areas tended to resent the more vocationally oriented courses believing that they would ultimately corrupt free inquiry (Tiratsoo, 2004). Eventually, owing to the existing university's preoccupation with research and the lack of academics with practical management experience, the B-schools came to emphasize academic rather than practical matters (Gröschl and Barrows, 2003). The typical $\mathrm{B}$-school is now an integral part of the parent university and conforms to the policies and practices of that institution (Watson, 2006).

The climate of universities changed in Britain in the mid-1970s and early 1980s. One influence was government policy and under Margaret Thatcher the government encouraged the advancement of managerial competence, which helped drive this change (Tiratsoo, 2004). Simultaneously, however, government funding restraints meant universities had to look for alternative sources of funding, whilst at the same time being pressured to accept more students (Deer, 2002). Business and management programmes were seen as attractive ways of developing income streams; the MBA flourished with high student demand and relaxed fee structures. As universities became more focused on commercial opportunities, they looked to the international market to recruit more students. In 1988, the Government exerted more power on educational systems when it passed the Educational Reform Act, which required universities to become more accountable, marketoriented and efficient (Deer, 2002). Also in the 1980s, research funding was subjected to a radical overhaul with the introduction of the Research Assessment Exercise, which distributed more research funding to those universities with an excellent record of accomplishment in research (Cooper and Otley, 1998; Saunders, Wong and Saunders, 2011). The growth has been enormous and now 120 universities have founded B-schools in the UK, mostly based on the American model (Tiratsoo, 2004; Zammuto, 2008). Currently, almost all universities have a B-school including the oldest institutions, with Oxford (Said School of Management) and Cambridge (Judge Institute) being late entrants into the arena.

The above historical overview shows that British and French B-schools started from quite different positions, but that since the 1960s convergence trends can be seen. This convergence has been influenced by the adoption to a large extent of the American model of $\mathrm{ME}$ in both countries (see Tiratsoo, 2004) and by the introduction of media rankings (e.g. Financial Times), which are based amongst other things on an assessment of teaching quality, students' increase in salary, degrees of internationalization of the faculty, university and national audits of research performance (Thomas and Wilson, 2011), and accreditation. Altogether the league tables and accreditations signal quality to students and play an important part in their decisions regarding where to study. Notwithstanding the influence of all these convergence factors, we concentrate here on how accreditation systems have impacted upon the convergence dynamics.

In what follows, we focus on the role of the dominant accreditation mechanisms in influencing convergence and divergence dynamics in ME. We develop a theoretical argument and elaborate upon it by reporting empirical data gained from interviews we conducted with Deans and/or 
Directors of Research of two EQUIS and AACSB accredited British university B-schools and of two French GECs. These data are supplemented by personal observations from the authors who have a rich experience of both French and UK B-schools (as faculty members and students).

\section{Gaining and sustaining accreditation}

\section{$A A C S B$ and EQUIS}

Accreditation in ME has been defined as 'a status granted to an institution ... that has been evaluated and found to meet or exceed stated criteria of education quality' (Young et al., 1983, p. 433). Over the past 20 years, ME has witnessed a surge in the number of international independent bodies overseeing quality through the medium of accreditation (Zammuto, 2008). Two business school accreditors that have come into prominence over the last 20 years are AACSB and EQUIS. These bodies actively promote approaches which significantly influence the decisions taken by B-schools in terms of recruitment of faculty and students, the design of programmes of study and governance, the attraction of additional resources to strengthen their reputation, as well as visibility and influence (Dameron and Durand, 2009; Mottis, 2008). Both EQUIS and AACSB are 'full service' accreditors, accrediting B-school programmes from undergraduate through to doctoral level.

AACSB is the largest and has the longest history in accrediting B-schools. The American Association of Collegiate Schools of Business, now the Association to Advance Collegiate Schools of Business (AACSB), was founded in 1916 by a group of leading American B-schools with the goal of enhancing the quality of ME at the collegiate level. To date, AACSB has granted accreditation to 152 institutions in 39 countries outside the USA (www.aacsb.net) with the first non-North American accreditation granted in 1995 to ESSEC Business School, France (White, Miles and Lavernier, 2009). AACSB's approach to accreditation is to focus on the assessment of learning outcomes as defined by each institution (Tullis and Camey, 2007) where institutions are typically required to have a prescribed curriculum exposing students to a wide array of business topics (McKee, Mills and Weatherbee, 2005; White, Miles and Lavernier, 2009). AACSB has grown into a global organization that is attempting to create a comprehensive set of accreditation standards that can be applied to B-schools located in virtually any country (White, Miles and Lavernier, 2009).

EQUIS primarily came into being as a response to the AACSB's original strategy to accredit only domestic North American B-schools. The EQUIS label evolved from the development of the EFMD in the mid-1970s to target those B-schools that were aiming to make an impact beyond their domestic frontiers (Urgel, 2007). Created in 1997, the EQUIS label was designed as the first international system of quality assessment, improvement and accreditation of higher education institutions in management and business administration. EQUIS is based on continuous improvement through regular comparison with other institutions with the resultant award conferring that an institution is international in terms of the student body, faculty and research undertaken (Nioche, 2007). At present, EFMD has 131 EQUIS accredited schools across 38 countries (www.efmd.org). Britain and France lead the way in EQUIS accreditation with 23 and 18 accredited schools respectively.

Whilst B-schools seek accreditation when they see a potential for increasing competitive advantage domestically, they may also believe that a lack of accreditation would reduce their ability to offer services on the global market when faced with competition from other certified providers (Zammuto, 2008). Also, accreditation has stimulated rivalry as non-accredited schools seek to reduce the differential advantage held by accredited schools by improving the quality of their programmes and seeking accreditation themselves. Furthermore, cross-border comparison is facilitated as the accreditation also functions as a form of international benchmarking (Marginson and van der Wende, 2007). Thus, we argue that the pursuit of accreditation fosters a form of competitive mimicry (Zammuto, 2008).

Expressed differently, accreditation can be considered as a source both of differentiation between accredited and non-accredited schools, as it allows for accredited B-schools to claim they offer quality programmes in the pursuit of increased visibility and greater potential funding opportunities, but also of homogenization, as progressively more and more B-schools gain accreditation and make the same claim (see 
Table 1): in reality, those achieving accreditation actually only gain competitive parity through this form of 'reactive adaptation' (Durand and Dameron, 2008, p. 77). Such dynamics prompt one key question: is accreditation a source of competitive advantage?

Taking an RBV position, we know that rare resources which are valuable, imperfectly imitable and non-substitutable (VRIN) are key resources for sustainable competitive advantage (Barney, 1991; Wernerfelt, 1984). Hence, by definition, a resource possessed by a large number of firms cannot be a source of advantage. At best, resources that are valuable but not scarce can be sources of competitive parity (Barney, 1995). This does not imply that these resources do not matter. They do matter, as they are needed to be considered a player in the industry, but they do not confer competitive advantage beyond this. Hence we suggest that gaining accreditation may be essential, but it is only a prerequisite.

\section{Accreditation from an $R B V$ and institutional perspectives}

Applying the RBV logic to British and French B-schools, in the late 1990s when there were only a few accredited schools such accreditation gave the schools a competitive advantage over those schools without it. EQUIS accreditation gave B-schools European exposure and AACSB accreditation brought American exposure. These B-schools also gained a reputation for quality and hence were able to brand themselves as 'top B-schools' (and thereby charge higher fees and attract 'stronger' students and faculty). In short, gaining accreditation has helped these B-schools access new markets and the development of a premium (focused differentiation) strategy. However, whilst early adopters certainly achieved some competitive advantage (Tullis and Camey, 2007), now that accreditation processes are more mature the fear is that accreditation may homogenize ME where national, regional and local differences are lost. With more and more B-schools achieving these accreditations, it has become necessary for B-schools to be perceived as top quality institutions. Taking an innovation perspective, we see accreditation as a form of innovation and the adoption and diffusion of accreditation by B-schools has created strategic convergence (Tzokas and Saren, 1997). However, with many schools accredited, accreditation has stopped being a source of heterogeneity and a strategic group (or 'elite club') has been created where accreditation has become the norm and a source of parity. Hence, taking an institutional theory perspective (Gaur and Kumar, 2009), accreditation has led to the creation of a new institutional context or organizational field (Meyer and Rowan, 1977). Organizational fields 'are characterized by the elaboration of rules and requirements to which individual organizations must conform if they are to receive support and legitimacy' (Scott and Meyer, 1983, p. 149). Legitimacy is the generalized perception or assumption that organizational actions are desirable, proper and appropriate within a socially constructed system of norms, values, beliefs and definitions (Suchman, 1995).

\section{Accreditation as a means of displaying quality}

As explained, EQUIS and AACSB are quality assurance schemes. They are a means of signalling to students and the wider business community that the accredited schools are legitimate and provide high quality programmes and prestige (Tullis and Camey, 2007). So, as suggested by institutional theory, B-schools conform to the accreditation process not to achieve superior performance but to gain legitimacy and resources (DiMaggio and Powell, 1983). Our interviewees' comments suggest that this is indeed the case. French B-schools deemed the EQUIS accreditation as particularly important for achieving international recognition. For one of the French B-school interviewees, there was no other rationale for the pursuit of this accreditation. AACSB accreditation was sought primarily for partnership with American schools, as it was felt that American B-schools would not collaborate with non-AACSB accredited schools. For the British B-schools, the pursuit of accreditation was also driven by the need to establish their credentials for high quality. Both sets of interviewees also highlighted that getting accreditation was important for their place in the global rankings. They felt that accreditation helped establish their position in the rankings and this is critical to their B-school's success as these rankings are perceived to be the main tool used by customers to select their schools: 
Accreditations do assist in all rankings especially the FT ranking ... so yes, it helps. (French B-school)

\section{Isomorphism}

We have seen so far that accreditation is sought because it helps establish a reputation for quality and international exposure, and we contend that with more and more B-schools pursuing accreditation as a means to secure competitive advantage a form of competitive mimicry is taking place:

We followed the trend for achieving accreditation as other top schools were. (French B-school)

In other words, accreditation has become the norm and is now seen by B-schools as being the 'appropriate' way to operate (Tolbert and Zucker, 1983). It is now taken for granted that top B-schools will be accredited and that, because of these norms, isomorphism across the schools is a likely consequence (Brewster, Wood and Brookes, 2008; Dacin, 1997). They will become alike. Institutional isomorphism occurs as individual actors and organizations adopt, or have imposed on them, a wider belief system and cultural frames that promote the replication of structures, activity patterns and cultural mores that are present in their environments (McKee, Mills and Weatherbee, 2005). This was reflected in our findings. French B-schools acknowledged that the pursuit of EQUIS promoted a focus on research and it was recognized that AACSB obliged the schools to clarify who they wanted to train, which markets they were operating in and their value proposition.

Both accreditations were believed to have added rigour to the process of quality improvement. For the British schools, our interviewees acknowledged that the process of gaining accreditation had been useful for guiding strategic planning. One British $\mathrm{B}$-school recognized that EQUIS had a particular impact on the internationalization of the B-school with the emphasis on international relationship development and the setting up of an international advisory board. AACSB accreditation has also been an important influence on introducing specific systems, such as databases for staff curriculum vitae and publications.

AACSB is very stringent in its requirements for academically qualified (AQ) and professionally qualified (PQ) status (Cavico and Mujtaba,
2010). Traditionally French B-schools have used a high percentage of part-time adjunct professors. Many adjunct professors are active practitioners in France and thus fulfil the PQ requirements. However, the emphasis over the last ten years has been to recruit more international AQ faculty. Additionally, the AACSB requirement for AQ is that faculty must be published in peer-reviewed scholarly journals. Mottis (2008) and Thietart (2009) both argue that this one factor has greatly influenced the increase in research and scholarly activity in France. Research in the English language is encouraged through the requirement to publish in English-speaking academic journals (Marginson and Rhoades, 2002). Additionally, the focus of research in France has shifted from one which was previously more applied in nature, contributing to the community it was supposed to serve, to one that focuses on a contribution to knowledge, where recommendation for practice is more of a by-product (Thietart, 2009). The British B-schools have traditionally recruited more AQ faculty than PQ faculty. Accordingly, approaches to faculty recruitment and research in British and French schools have become more aligned.

This is an example that shows that accreditation does influence convergence of approaches in both countries. Further evidence from our interviews goes some way in supporting this assertion. It was acknowledged by both French schools' interviewees that accreditation definitely was a key influence on strategy and strategic reflection as regards vision and mission, and strategic positioning. Their strategy was influenced by the rules of accreditation agencies, e.g. by emphasizing improvements in research. Interviewees in the British B-schools also felt that satisfying accreditation bodies was part of the focus of strategic planning. For one British B-school, it was recognized that EQUIS has had a significant influence on the development of international activities and in the reassessment of the school's vision. Hence with more and more schools achieving these accreditations they have stopped being a source of heterogeneity. Instead we see the formation of a new organizational field where accreditation is the norm and a source of parity in the sector:

Having the badges and being able to promote these is good, but many other schools can also promote 
this and today accreditation doesn't give the school a competitive advantage. (French B-school)

Kondra and Hinings (1998) proposed that organizations not only become similar in terms of the way they operate, they also become similar in terms of performance. This claim is highlighted through the observance of little movement in the positions of the top B-schools in the numerous ranking lists over recent years. One could also add that this pursuit of accreditation runs the risk that B-schools become forced to assimilate programmatic accreditation elements leading to homogenization, which results in the creation of bland, homogenized and ultimately uncompetitive B-schools (Cavico and Mujtaba, 2010). The rigid pursuit of accreditation by B-schools can act as a form of 'internal myopia' (Malini Reddy, 2008) with institutions focusing too heavily on their internal operations to the detriment of important signals from their external environments. A central tenet of strategy is that organizations must achieve strategic flexibility if they are to survive and prosper over the longer term (Kumar and Usunier, 2001); our interviewees recognized this. The French B-schools felt that energy, money and competences could be put to better use to leverage the B-schools' performance, e.g. by conducting research in a manner that was of more practical relevance to companies and students. The British felt that the huge investment put into gaining and maintaining accreditation had detracted from other important issues such as research outputs and a greater focus on national ranking systems such as the National Student Survey (NSS), which focuses on the students' learning experience:

We would do research differently and this research would be more useful for companies, students and others. Accreditation focuses on more academic than practitioner research. For them, pedagogical research and practitioner research does not exist. (French school)

We are not obsessed by accreditations. It is not the school's preoccupation. Things such as the NSS results are - this is an absolute obsession. (British school)

This leads us to raise the question: what is the future for French and British B-schools? We shall attempt to develop an answer to this question in the next section.

\section{Future scenarios for British and French business schools}

Will the top B-schools, since they face the same set of environmental conditions, be isomorphic to one another and resemble each other in a few years (Dacin, 1997)? Can they break out of their institutional field? Can they develop VRIN resources that are supported by the organizational field in which they operate (Oliver, 1997)? As argued so far, conforming to the rules, and specifically here to the standards demanded by EQUIS and AACSB, is now a way of achieving legitimacy, increased prestige and professional acceptance, and of winning funding (Oliver, 1991). In short, the pursuit of accreditation by an institution is a practical attempt to gain or reinforce legitimacy and therefore adds to the B-school's perceived credibility in the market. There is circularity to these actions as they also serve to reinforce the legitimacy and standing of AACSB and EQUIS.

Oliver (1997) suggests that human capital transfers and social and professional relations are sources of organizational homogeneity. These are key to international accreditation standards. Indeed in an attempt to improve research visibility the key strategy for many B-schools in both countries is to recruit research professors who publish in the best journals and are externally visible. Thus, as just argued and shown above, recruitment is influenced by the institutional context the schools operate in. The recruitment patterns of the schools are shaped by mimetic isomorphism and they also reinforce it: 'Personnel professionals, working individually and through networks ... and professional personnel journals, are important in the diffusion of particular responses to the legal environment. The frequent movement of personnel in the corporate world spreads ideas and governance practices among organizations' (Edelman, 1990, p. 1410).

Kondra and Hinings (1998) suggest that mimetic behaviour may persist even if organizations are aware that their performance could be improved if they did not conform, creating risk aversion: "if all organizations "play by the rules" everyone gets to keep their jobs, thereby providing a strong incentive not to question institutional norms' (Kondra and Hinings, 1998, p. 749). Our 
interviewees support the argument that mimetic behaviour generates risk aversion in accredited B-schools:

With accreditation you are really trapped; when you enter accreditation ... you reach a point of no return. No B-school can afford to say they decided to quit accreditation as they felt they were good enough without them. Whilst this move might be done collectively, it couldn't be done by an individual school, and collectively it was doubtful due to game theory. The strategy has to operate within the parameters of accreditation. (French B-school)

Having got accreditation there is no way we want to lose it. We will do what we need to do to keep it. (British B-school)

Each B-school felt that not having accreditation was less risky than losing accreditation. Accreditation was felt in this respect to be self-sustaining.

McKee, Mills and Weatherbee (2005) suggest that an institution may deviate from socially accepted norms but only if this deviation goes unnoticed. The problem though is that mimetic isomorphism may be negative to performance (Barreto and Baden-Fuller, 2006) because, as explained earlier, isomorphism reduces uniqueness and hence advantage. Consequently, we suggest that B-schools may want to avoid conforming whilst at the same time maintaining the advantages of accreditation.

Oliver (1991) acknowledges that some organizations only comply with the norms for pragmatic reasons and are not blinded by them. Based on the literature and on our interview data, we argue that as accreditation systems are entering a mature phase of their lifecycle this is what is happening for British and French B-schools; such organizations may be ready to grasp new opportunities and change the way they do things. The ability of organizations embedded in their organizational field to change is referred to as 'the paradox of embedded agency' (Seo and Creed, 2002). Greenwood and Suddaby (2006) report that economic interest is one of the reasons firms embedded in a field may change. This may well happen to B-schools as they constantly seek to develop their competitive advantage. One question remains, however: will they become renegade and stop complying with the institutional norms and introduce diversity or will they change but still operate within the 'rules'?
We would like to suggest that, as a whole, B-schools will acquiesce to institutional pressures as they gain legitimacy from being accredited and financially benefit from it. However, in view of our RBV argument that accreditation has become a source of parity and that B-schools need to find new ways of generating competitive advantage, we propose that some B-schools are likely to adopt a compromise strategy (Oliver, 1991): they will conform to a large extent but this will be only partial as they will promote their own interests. Thus, such schools will adopt a strategic approach to legitimacy (McKee, Mills and Weatherbee, 2005; Suchman, 1995). B-schools might change, but will still be acting within the rules of accreditation. In this approach, institutions will not defy accreditation because they are dependent on these bodies for legitimacy reasons. It would not be in their interests to do so as accreditation is a taken for granted requirement for students seeking the best B-schools (Oliver, 1991). Our findings seem to confirm this scenario. All schools interviewed admitted that whilst accreditation guided strategic planning and thinking, the requirements of these did not dominate approaches to planning, where suggestions were acknowledged as recommendations and not mandatory. Strategies of compromise that mix approaches to ME rooted in accreditation, yet with approaches that offer something different, were seen as possible from our interviews with the French B-schools. It was believed they had a different role in the globalized education market owing to their European location:

We are based in Europe, in France. We know we have different views about world globalization.

(French B-school)

They emphasized that Europe is a 'cultural continent' and that as such European B-schools were well placed to educate students in multicultural skills that are key to the globalized world. Our French B-school interviewees proposed a number of strategies for the future underlining this commitment to a compromise approach. Such strategies included attempts to differentiate by way of recruitment, innovations in curriculum content, and the introduction of elective modules in the humanities that were felt to be an important means of differentiation to what was being offered in the USA and Asia and also linked to the French cultural tradition. Additionally, they emphasized 
a refocusing of more practice-oriented research and pedagogy and increased opportunities for collaboration with universities that would enable them to gain size, resources and power for future competition. Such an emphasis was based on concentration within the sector due to the maturity stage of the lifecycle of B-schools. It was recognized, however, that these changes would be put in place within the bounds of the rules of accreditation.

Whilst our interviewees in British B-schools also suggested that working within the parameters of accreditation was important, there was less emphasis on doing different and unique things. Rather, they felt there were already a number of important areas that the B-schools should continue to focus on outside the remit of the accreditation bodies. In particular, they stressed the priority for British B-schools to increase the quality of their research and teaching in line with Higher Education Funding Council requirements. Additionally, placing more emphasis on national surveys was seen as a key priority. The perception was that, although accreditation was important, it did not predominate thinking in future strategy development.

Even if there is no defiance can B-schools diverge? Feldman and Pentland (2003) suggest that organizational routines can be decomposed into two: the ostensive aspect of the routine, i.e. the structure or abstract understanding of the routine, and the performative aspect, i.e. the actual performance of the routine. Here, having the 'badge' EQUIS or AACSB would be the ostensive aspect, but the processes behind how the accreditation is achieved and maintained within the schools are different. This is linked with the notion of strategic legitimacy (Suchman, 1995). Thus, in effect, there is a source both of homogeneity and of heterogeneity within the accreditation system: B-schools with the same accreditation goals experience the same convergence pressures but may operate different processes in achieving accreditation. Institutions are free to manage or construct legitimacy through substantive and material change or symbolic activity (McKee, Mills and Weatherbee, 2005). As seen above in our examples this is the case for British and French B-schools who have different cultures and ways of operating due to their history and original raison d'être. This argument can also be combined with Hoffman's (2001) position.
He explains (2001, pp. 136-137) that 'the form of organizational response is as much a reflection of the institutional pressures that emerge from outside the organization as it is the form of organizational structure and culture that exist inside the organization'. British and French B-schools have strong and different heritages that are unlikely to be wiped away easily. This influences strategy formulation 'as it derives from assumptions regarding relationships with the environment as well as relationships among people' (Schneider, 1989, p. 149). Schools in France clearly acknowledged this in their strategic thinking with choices being based on resources and constraints prevalent in the French environment:

\begin{abstract}
We have some plans ... would like to change the way we recruit students for the GEC programme, but difficult to do as it is under Government control ... want to be innovative in the way we provide multi-cultural skills. ... The school would do this by keeping in the bounds of accreditation. This move would not take the school outside the bounds of accreditation. (French B-school)
\end{abstract}

The British schools have always done things slightly differently to that proposed by dominant accreditation bodies, but at the same time acknowledging that accreditation is an alternative mechanism in the pursuit of quality improvement. It would seem that institutions should and do have the freedom to redefine their purposes and objectives outside the requirements of dominant accreditation agencies. This approach is recognized by John Fernandes, AACSB President and CEO, who suggests that 'Schools will pursue areas of emphasis that they have the energy, the mission, the stakeholders, the support and the faculty, to be very good at and that is part of the world's ME agenda' (Carraher, 2009, p. 133).

\section{Conclusion}

Since their formation, British and French B-schools have diverged in their purpose, characteristics and culture. Although at first it might appear that convergence in approaches to ME in both countries occurred through the adoption of the American model, our presentation of the evolution of ME reveals that differences in approach 
still exist due to the prevailing cultural and institutional characteristics inherent in each country. Our interviewees acknowledge the influence of the American model in their operations albeit only as a partial influence. For the French, it was felt that ME had been rooted in the American style of teaching from the early beginnings and that the schools that evolve 'Americanize' as a means to internationalize, particularly for research purposes. The British schools acknowledge the influence of the American model, particularly since the 1960 s, in terms of the breaking down of teaching into the functional areas. Nevertheless, ME still shows pathways of divergence with B-schools in neither country wholeheartedly adopting the American model but retaining their own distinct approaches, which reflect cultural differences. While we acknowledge the influence of 'Americanization', our aim was to explore how leading accreditation mechanisms are currently influencing convergence.

Gaining the approval of both, or either, of the leading accreditation bodies has been a sign of quality that has an important influence on students' buying decisions. Not surprisingly, they have both significantly influenced the decisions taken by ME institutions across a variety of domains in their strategic planning and market positioning. This pursuit of accreditation is a form of competitive mimicry leading to a degree of homogeneity amongst top B-schools. Whilst we might criticize the accreditation process as a force depriving $\mathrm{ME}$ of its national distinctiveness, our institutional theory analysis suggests much more complex and optimistic dynamics. In short, whilst the organizational field 'pushes' B-schools towards isomorphism, an RBV analysis suggests that to outperform competitors the schools need to be heterogeneous and must have a strategy that is different (and not easily replicable) from their competitors. With more schools achieving accreditation, this form of differentiation becomes less and less effective at distinguishing the excellent from the good. As a result, achieving accreditation is a necessary precursor required by B-schools to perform on the international stage rather than a means to achieve competitive advantage. Viewed in this light, we see accreditation as a period of homogenization, albeit one containing a lot of variation and individual interpretation. Perhaps more importantly, this homogenization becomes the new impetus for divergence as B-schools look to alternative scenarios in pursuit of competitive advantage.

Although the American and accreditation forces have homogenized B-schools over the past 50 years in Britain and France (and elsewhere) it appears that they may help B-schools return to their roots. The accreditation agencies have brought about homogenization because people across the world have agreed on the basic level of provision that a B-school should offer. In essence, they have established the quality base that all B-schools should exhibit as a matter of course. There has been homogenization because so many schools were below this level and they have had to work hard to improve their procedures. Once they have reached this level, the B-schools can legitimately make claims about the high quality of their research and teaching. But there are now many who have reached this level, so those achieving these symbols of high quality will have to find other ways to achieve competitive advantage. Without jeopardizing their accreditation, we would expect B-schools to pursue individual and separation strategies to differentiate themselves from others. There are already signs of this happening. The proximity of City University to the financial district of London is reflected in a suite of courses in their B-school (Cass Business School) that prepare students for specialized financial careers. BEM Management School in Bordeaux can demonstrate excellence in wine related businesses. In such examples we see the emergence of B-schools that reflect their particular location, history and culture. But they do this upon high quality foundations. Ironically, therefore, homogenization will help B-schools find their own distinctive identities.

\section{References}

Ahola, S. (2005). 'Global and local priorities in higher education policies: a headache at the national level?', Tertiary Education and Management, 11, pp. 37-53.

Ayoubi, R. M. and R. Al-Habaibeh (2006). 'An investigation into international business collaboration in higher education institutions: A case study of international partnerships in four UK leading universities', International Journal of Education Management, 20, pp. 380-396.

Barney, J. B. (1991). 'Firm resources and sustained competitive advantage', Journal of Management, 17, pp. 99-120.

Barney, J. B. (1995). 'Looking inside for competitive advantage', Academy of Management Executive, 9, pp. 49-61.

Barreto, I. and C. Baden-Fuller (2006). 'To conform or to perform? Mimetic behaviour, legitimacy-based groups and 
performance consequences', Journal of Management Studies, 43, pp. 1559-1581.

Brewster, C., G. Wood and M. Brookes (2008). 'Similarity, isomorphism or duality? Recent survey evidence on the human resource management policies of multinational corporations', British Journal of Management, 19, pp. 320-342.

Carraher, S. (2009). 'Business education accreditation and the changing global marketplace: John Fernandes of AACSB', Journal of Applied Management and Entrepreneurship, 14, pp. 128-139.

Cavico, F. J. and B. G. Mujtaba (2010). 'An assessment of business schools: student retention, accreditation, and faculty scholarship challenges', Contemporary Issues in Education Research, 3, pp. 107-118.

Chisholm, A. (2011). 'European business schools, a growing market', EFMD Global Focus, 03, 1, www.efmd.org; accessed June 2011.

Cooper, C. and D. Otley (1998). 'The 1996 Research Assessment Exercise for business and management', British Journal of Management, 9, pp. 73-89.

Cret, B. (2007). 'Stratégies d'établissement, stratégies d'accréditation', Revue Française de Gestion, 178-179, pp. 233-250.

Dacin, M. T. (1997). 'Isomorphism in context: the power and prescription of institutional norms', Academy of Management Journal, 40, pp. 46-81.

Dameron, S. and T. Durand (2009). '2020 vision: a dual strategy for European Business schools', EFMD Global Focus, 03, 1, www.efmd.org/globalfocus; accessed 12 June 2011.

Deer, C. (2002). Higher Education in England and France since the 1980s. Oxford: Symposium Books.

DiMaggio, P. J. and W. W. Powell (1983). 'The iron cage revisited: institutional isomorphism and collective rationality in organizational fields', American Sociological Review, 48, pp. $147-160$.

Durand, T. and S. Dameron (2008). The Future of Business Schools: Scenarios and Strategies for 2020. Basingstoke: Palgrave Macmillan.

Durand, T. and S. Dameron (2011). 'Where have all the business schools gone?', British Journal of Management, 22, pp. 559-563.

Edelman, L. B. (1990). 'Legal environments and organizational governance: the expansion of due process in the American workplace', American Journal of Sociology, 95, pp. 14011414.

Engwall, L. and R. Danell (2011). 'Britannia and her business schools', British Journal of Management, 22, pp. 432-442.

Feldman, M. S. and B. T. Pentland (2003). 'Reconceptualizing organizational routines as a source of flexibility and change', Administration Science Quarterly, 48, pp. 94-118.

Gaur, A. S. and V. Kumar (2009). 'International diversification, business group affiliation and firm performance: empirical evidence from India', British Journal of Management, 20, pp. 172-186.

Granink, D. (1972). Managerial Comparisons of Four Developed Countries: France, Britain, United States and Russia. Cambridge, MA: MIT Press.

Greenwood, R. and R. Suddaby (2006). 'Institutional entrepreneurship in mature fields: the Big Five accounting firms', Academy of Management Journal, 49, pp. 27-48.

Gröschl, S. and C. W. Barrows (2003). 'A cross-cultural comparison of French and British managers: an examination of the influence of higher education on management style', Tourism and Hospitality Research, 4, pp. 228-245.

Hoffman A. J. (2001). 'Linking organizational and field level analyses: the diffusion of corporate environmental practice', Organization and Environment, 14, pp. 133-156.

Jamali, D. and B. Neville (2011). 'Convergence versus divergence of CSR in developing countries: an embedded multilayered institutional lens', Journal of Business Ethics, 102, pp. 599-621.

Kipping, M., B. Üsdiken and N. Puig (2004). 'Imitation, tension, and hybridization: multiple "Americanizations" of management education in Mediterranean Europe', Journal of Management Inquiry, 13, pp. 98-108.

Kondra, A. Z. and C. R. Hinings (1998). 'Organizational diversity and change in institutional theory', Organization Studies, 19, pp. 743-767.

Kumar, R. and J.-C. Usunier (2001). 'Management education in a globalizing world', Management Learning, 32, pp. 363391.

Lambert, R. (2008). 'The importance of investing in world class universities', Business Voice, 12, pp. 6-11.

Malini Reddy, Y. (2008). 'Global accreditation systems in ME: a critical analysis', South Asian Journal of Management, 15, pp. 61-80.

Marginson, S. and G. Rhoades (2002). 'Beyond national states, markets, and systems of higher education: a glonacal agency heuristic', Higher Education, 43, pp. 281-309.

Marginson, S. and M. van der Wende (2007). 'Globalization and higher education', OECD Education Working Paper 8, pp. 1-83. Paris: OECD.

McKee, M. C., A. J. Mills and T. Weatherbee (2005). 'Institutional field of dreams: exploring the AACSB and the new legitimacy of Canadian business schools', Canadian Journal of Administrative Sciences, 22, pp. 288-300.

Meyer, J. W. and B. Rowan (1977). 'Institutionalized organizations: formal structure as myth and ceremony', American Journal of Sociology, 83, pp. 340-363.

Mottis, N. (2008). 'L'Europe des masters en formation: processus de Bologne au travers des cas allemand, anglais et français', Gérer et Comprendre, 94, pp. 25-37.

Nioche, J.-P. (2007). 'La montée en puissance des accréditations non étatiques', Revue Française de Gestion, 33, pp. 219232.

Noorda, S. (2011). 'Future business schools', Journal of Management Development, 30, pp. 519-525.

Oliver, C. (1991). 'Strategic responses to institutional processes', Academy of Management Review, 16, pp. 145-179.

Oliver, C. (1997). 'Sustainable competitive advantage: combining institutional and resource-based views', Strategic Management Journal, 18, pp. 697-713.

Ramirez, M. (2004). 'Comparing European approaches to ME, training and development', Advances in Developing Human Resources, 6, pp. 428-450.

Saunders, J., V. Wong and C. Saunders (2011). 'The research evaluation and globalization of business research', British Journal of Management, 22, pp. 401-419.

Schneider, S. C. (1989). 'Strategy formulation: the impact of national culture', Organization Studies, 10, pp. 149-168.

Scott, W. R. and J. W. Meyer (1983). 'The organization of societal sectors'. In J. W. Meyer and W. R. Scott (eds), Organizational Environments: Ritual and Rationality, pp. 129153. Beverly Hills, CA: Sage. 
Seo, M. G and W. E. D. Creed (2002). 'Institutional contradictions, praxis and institutional change: a dialectical perspective', Academy of Management Review, 27, pp. 222247.

Starkey, K. and N. Tiratsoo (2007). The Business School and the Bottom Line. Cambridge: Cambridge University Press.

Suchman, M. C. (1995). 'Managing legitimacy: strategic and institutional approaches', Academy of Management Review, 20, pp. 571-610.

Thietart, R. (2009). 'The research challenge of French business schools: the case of the Grandes Ecoles', Journal of Management Development, 28, pp. 711-717.

Thomas, H. (2008). 'The future of business schools'. In T. Durand and S. Dameron (eds), The Future of Business Schools: Scenarios and Strategies for 2020, pp. 117-132. Basingstoke: Palgrave Macmillan.

Thomas, H. and E. Cornuel (2011). 'Business school futures: evaluation and perspectives', Journal of Management Development, 30, pp. 444-450.

Thomas, H. and A. D. Wilson (2011). " "Physics envy", cognitive legitimacy or practical relevance: dilemmas in the evolution of management research in the UK', British Journal of Management, 22, pp. 443-456.

Tiratsoo, N. (2004). "The "Americanization" of management education in Britain', Journal of Management Inquiry, 13, pp. 118-126.

Tolbert, P. S. and L. G. Zucker (1983). 'Institutional sources of change in the femoral structure of organizations: the diffusion of civil service reform, 1880-1935', Administrative Science Quarterly, 28, pp. 22-39.

Tullis, K. J. and J. P. Camey (2007). 'Strategic implications of specialized business school accreditation: end of the line for some business education programs?', Journal of Education for Business, 83, pp. 45-51.
Tzokas, N. and M. Saren (1997). 'Building relationship platforms in consumer markets: A value change approach', Journal of Strategic Marketing, 5, pp. 105-120.

Urgel, J. (2007). 'EQUIS accreditation: value and benefits for international business schools', Journal of Management Development, 26, pp. 73-83.

Üsdiken, B. (2004), 'Americanization of European ME in historical and comparative perspective: a symposium', Journal of Management Inquiry, 13, pp. 87-89.

Vandenabeele, W. and S. Van de Walle (2008). 'International differences in public service motivation: Comparing regions across the world'. In J. L. Perry and A. Hondeghem (eds), Motivation in Public Management. The Call of Public Service, pp. 223-244. Oxford: Oxford University Press.

Watson, S. (2006). 'A global guide to ME's Global Foundation for Management Education', EFMD-AACSB International, First Edition pp. 263-268.

Wernerfelt, B. (1984). 'A resource-based view of the firm', Strategic Management Journal, 5, pp. 171-180.

White, J. B., M. P. Miles and W. Lavernier (2009). 'AACSB International and the management of its brand: implications for the future', Journal of Management Development, 28, pp. 407-413.

Wilson, J. F. (1996). 'Management education in Britain: A compromise between culture necessity'. In R. P. Amdam (ed.), Management Education and Competitiveness: Europe, Japan and United States. London and New York: Routledge.

Young, K. E., C. M. Chambers and H. R. Kells (1983). Understanding Accreditation: Contemporary Perspectives, Issues and Practices in Evaluating Educational Quality. San Francisco: Jossey-Bass.

Zammuto, R. F. (2008). 'Accreditation and the globalization of business', Academy of Management Learning and Education, 7, pp. 256-268.

Lisa Thomas is Assistant Professor of Strategy at IESEG School of Management, Paris, France. Prior to this Lisa was lecturer in strategy at Leicester Business School, De Montfort University, Professeur Associé in Management at Groupe Sup de Co, La Rochelle, France, and lecturer in Strategy at Cardiff Business School, Cardiff University.

Jon Billsberry is Professor of Management at Deakin University. He is Chair of the Management Education and Development Division of the Academy of Management and Editor-in-Chief of the Journal of Management Education. His research interests are in the areas of organizational fit and misfit, the cinematic portrayal of work and working life, and innovation in management education.

Véronique Ambrosini is a Professor of Management (Strategic Management) at Monash University, Australia. She was previously a Professor of Strategic Management at the University of Birmingham and at Cardiff University (UK). Her research is conducted essentially within the resource-based and dynamic capability view of the firm and takes a strategy as practice perspective.

Harry Barton is Head of the Division of Human Resource Management and Chair of the Research Directorate within Nottingham Business School, Nottingham Trent University. Prior to this Harry held posts in policy development, research and management within the Metropolitan Police, Audit Commission, District Audit and Cardiff Business School. 